（東京工業大学燃料科学研究所）（昭和 26 年 11 月 8 日受理）

\title{
（149）潤滑油の油性に関す、る研究(第13 報)
}

\section{飽和脂肪酸薄膜の整流作用一油分子の方向配列一について}

\author{
櫻 井 俊 男 - 古 沢 昭
}

飽和脂肪酸の油性に関寸る研究については従来多くの報告に接 している。これらの報告のうらには相互に関連性の認められるも のもある。例えば Bowden 氏の動摩擦係数の湘定結果1)と菅氏の 電子迴折法による結果 $\left.{ }^{2}\right)$ との間には，密接な関連性が認められて いる。すなわち飽和脂肪酸系列化合物の鋼面間に於て示す動摮擦 係数の傾向は孷素数 $\mathrm{C}_{6}$ を境界として一定值に達し，一方金属表 面上に於て明かな方向配列を示すに至る炭素数は- $\mathrm{C}_{4} \sim \mathrm{C}_{6}$ である。 しかし電子䢙折法による結果は一固体表面上にある油分子の方向 配列であり，境界摩擦と油分子の方向配列との関連性を論ずるに は，二固体面間にあつて両表面の影響並に荷重を受けた油分子の 状態が検討せられることが望ましい。ここには飽和脂肪酸として $\mathrm{C}_{3} \mathrm{H}_{6} \mathrm{O}_{2}$ のプロピオン酸から $\mathrm{C}_{18} \mathrm{H}_{38} \mathrm{O}_{2}$ のステフ.リン酸に至る 10 個の脂肪酸の薄膜が鋼二面間に於て示す整流作用について, 静的 条件亚に一定荷重の下に垁験を行い, 脂肪酸分子の方向配列につ いて検討して Bowden 氏及改び营氏の結果と対比して飽和脂肪酸 油膜の潤滑機構について考察した。

\section{实験方法並に試料}

従来摩摖係数の測定に用いだブロックゲーヂ及び鋼ボールを試 験片として使用し, 新にラップ仕上した清净なブロックゲーヂ表 面に淕布法により薄膜（通常 $200 \AA$ の桁にあるといわれる）をつ くつた。なお室温より融点の高いものは熔融状態に於て粱布膜を つくり，これらの薄膜上に鋼ボールをのせて第11 報の方法”之全 く同様に，整流作用並に電圧变化をオッシログラフ写真に記録し た。使用した飽和脂肪酸はプロピオン酸(Merk 製品), 酷酸, キ ッソウ酸, カプロン酸(以上武田製品), カプリル酸, カプリン酸, ラウリン酸, ミリスチン酸, パルミチン酸, ステアリン酸（以上 日本油脂製品）をそれぞれ烝溜法或は再結晶泆によつて精製し， その性状は次のようなるのである。

\section{第 1 表 飽和脂助酸の性状}

\begin{tabular}{|c|c|c|c|c|c|}
\hline \multirow{2}{*}{ 脂肪酸 } & \multirow{2}{*}{ 分子式 } & \multirow{2}{*}{$d_{4}^{50}$} & \multirow{2}{*}{$n_{\mathrm{D}}^{40}$} & \multicolumn{2}{|c|}{ 中 和 価 } \\
\hline & & & & 実剆值 & 計算値 \\
\hline プロピオン酸 & $\mathrm{C}_{3} \mathrm{H}_{6} \mathrm{O}_{2}$ & 0.9950 & 1.3876 & 756.6 & 757.3 \\
\hline 酪 . 酸 & $\mathrm{C}_{4} \mathrm{H}_{8} \mathrm{O}_{2}$ & 0.9592 & 1.3988 & 636.2 & 636.8 \\
\hline キッソゥ酸 & $\mathrm{C}_{5} \mathrm{H}_{10} \mathrm{O}_{2}$ & 0.9415 & 1.4100 & 549.6 & 549.3 \\
\hline カプロン酸 & $\mathrm{C}_{6} \mathrm{H}_{12} \mathrm{O}_{2}$ & 0.9208 & 1.4167 & 482.7 & 483.0 \\
\hline カプ リ几酸 & $\mathrm{C}_{8} \mathrm{H}_{18} \mathrm{O}_{2}$ & m.p. 16 & $\sim 16.7$ & 389.3 & 389.2 \\
\hline カプリン酸 & $\mathrm{C}_{10} \mathrm{H}_{20} \mathrm{O}_{2}$ & m. p. 31 & $\sim 31.7$ & 325.5 & 325.9 \\
\hline ラウリン酸 & $\mathrm{C}_{12} \mathrm{H}_{21} \mathrm{O}_{2}$ & m. p. 43 & $\sim 44.1$ & 280.0 & 280.2 \\
\hline ミリスチシ酸 & $\mathrm{C}_{14} \mathrm{H}_{28} \mathrm{O}_{2}$ & m.p. 52 & $7 \sim 53.7$ & 246.2 & 245.8 \\
\hline パルミチン酸 & $\mathrm{C}_{10} \mathrm{H}_{32} \mathrm{O}_{2}$ & m. p. 63 & $0 \sim 64.0$ & 218.2 & 218.9 \\
\hline ステアリン酸 & $\mathrm{C}_{18} \mathrm{H}_{36} \mathrm{O}_{2}$ & m. p. 69 & $0 \sim 70.0$ & 197.7 & 197.3 \\
\hline
\end{tabular}

1) F.P. Bowden, L. Leben, Phil. Trans. 239, 1 (1940).

2）菅 莪夫，理研啾報 22,199(1943).

3) 桜井俊男, 古沢 昭, 工化 55, 245(1952).
整流作用の湘定にあたつては鋼試験片は電気恒温気浴中に れ, 融点が室温以上の脂肪酸はそれぞれの融点以上（たたし枟香 温度以下と考えられる温度)に於て测定を行つた。

\section{実 験 結 果}

高級脂肪酸類は本測定温度範囲に於て，化学的にも比教的安可 であるが，低級脂肪酸類は室温に於てす鋼表面と容易に反応を走

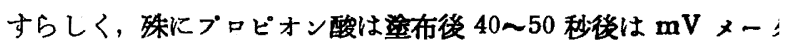
一の指針の振動著しく湘定不可能々なるここの際, 鋼表面力源臽を 起していることが助かにわかる。従つて $\mathrm{C}_{3} \sim \mathrm{C}_{6}$ の脂肪酸は 後 40〜60 秒以内に測定を終了した。测定結果を第 2 表に示与。 それぞれの $\mathrm{mV}$ の值は 30 回の測定值の算術平均值を以て示した

第 2 表 飽和脂肪酸の整婊作用

\begin{tabular}{|c|c|c|c|c|}
\hline 脂 肪 酸 & 剆定温度 $\left({ }^{\circ} \mathrm{C}\right)$ & $\mathrm{mV}$ & 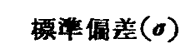 & $\mu \mathbf{A}^{*}$ \\
\hline $\mathrm{C}_{3} \mathrm{H}_{8} \mathrm{O}_{2}$ & 11.0 & 4.9 & 0.5 & 13.0 \\
\hline $\mathrm{C}_{4} \mathrm{H}_{8} \mathrm{O}_{2}$ & 10.5 & $12.5^{\circ}$ & 0.3 & 33.4 \\
\hline $\mathrm{C}_{6} \mathrm{H}_{10} \mathrm{O}_{2}$ & $10.5^{\prime}$ & 21.0 & 0.03 & 56.1 \\
\hline $\mathrm{C}_{6} \mathrm{H}_{12} \mathrm{O}_{2}$ & 11.0 & 26.8 & 0.3 & 71.7 \\
\hline $\mathrm{C}_{8} \mathrm{H}_{16} \mathrm{O}_{2}$ & $21.0 \sim 22.0$ & 28.5 & 2.2 & 76.2 \\
\hline $\mathrm{C}_{10} \mathrm{H}_{20} \mathrm{O}_{2}$ & $35.0 \sim 36.0$ & 29.8 & 1.6 & 79.7 \\
\hline $\mathrm{C}_{12} \mathrm{H}_{24} \mathrm{O}_{2}$ & $50.0 \sim 51.0$ & 28.6 & 1.9 & 76.5 \\
\hline $\mathrm{C}_{14} \mathrm{H}_{28} \mathrm{O}_{2}$ & $60.0 \sim 61.0$ & 30.2 & 1.1 & 80.7 \\
\hline $\mathrm{C}_{16} \mathrm{H}_{32} \mathrm{O}_{2}$ & $69.0 \sim 70.0$ & 30.1 . & 1.9 & 80.5 \\
\hline $\mathrm{C}_{18} \mathrm{H}_{38} \mathrm{O}_{2}$ & $79.0 \sim 80.0$ & 30.2 & 1.0 & 80.7 \\
\hline
\end{tabular}

*ね miVの值から換算した数值である。

又, 酪酸, キッソウ酸, カプロン酸, カプリル酸、ハルミチ 酸の場合のオッシャグラフ写真を第 1 図 A, B , C, D, E に揭げ 写真より求められる整流比及び振幅娍少兆を第 3 表に示す。

第 3 表 館和脂肪酸の振幅減少率及び整流比

\begin{tabular}{|c|c|c|c|c|}
\hline & 脂 & 眆・酸 & 振幅減少率 $(\mathbf{a} / \mathrm{b})$ & 整流比 $(\mathbf{c} ; \mathrm{d})$ \\
\hline & 酪 & 酸 & 1.5 & 1.0 \\
\hline & $\neq$ & ソウ酸 & 1.8 & 1.1 \\
\hline & カ & ロン酸 & 7.0 & 1.3 \\
\hline & カ & リル酸 & 8.2 & 1.4 \\
\hline & パ $n$ & ミチン酸 & 10 & 1.4 \\
\hline
\end{tabular}

第 2 表の各脂肪酸薄膜の示寸警流作用の結果は，分子旦の最 小さなプロビオン酸の場合が最む小さく, 分子量を增加するに い逐次大きくなり $\mathrm{C}_{3} \rightarrow \mathrm{C}_{6}$ までほぼ直的的に增大し， $\mathrm{C}_{6}$ のカブ ン酸と $\mathrm{C}_{8}$ のカプリル酸との差は僅少である。更に $\mathrm{C}_{8}$ から C のステアリン酸に至る間ほぼ一定の值を示すようになり、この はパルミチン酸累椯膜の 5〜9 分子層の場合の值に近似して る。すなわち飽和脂肪酸系の整流作用に関する炭策数の境界は にあることは明かである。なおこの頃向は第 1 図の各写真，第 表の整流比の值及び第 2 四より傕諗することができる。 


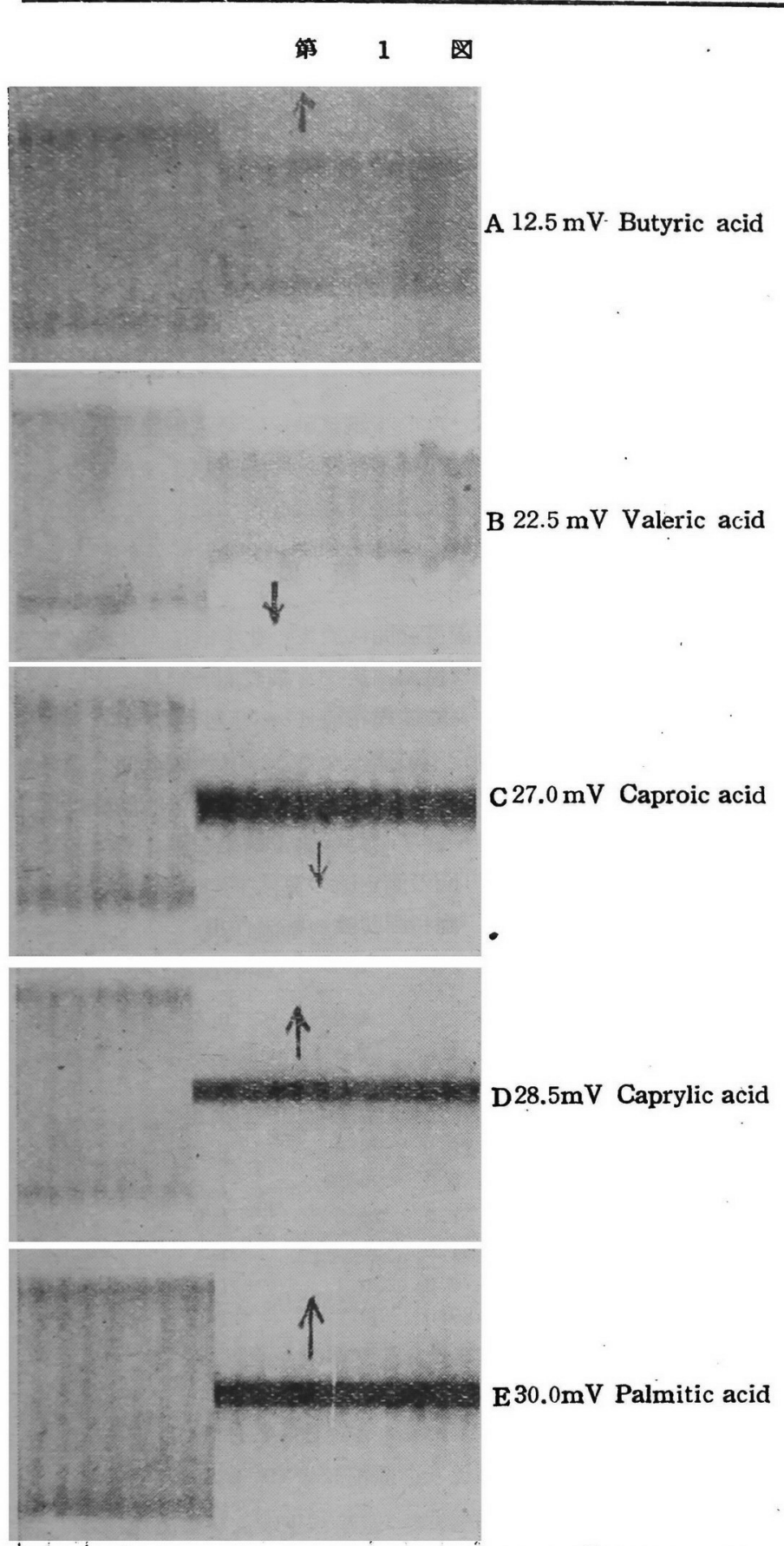

第 1 図の各军真に記してある $\mathrm{mV}$ の值はそれぞれ撮影時の值 である。

\section{実験結果の考察}

ラッブ仕上した清净な鋼表面に叙布朕をつくるとき，鋼表面の 徽視的凹部や舊裂にる油分子が入りこんで, 表面は一沁油膜で覆 われるものと考えられる。従つて油膜の厚さは全表面にわたつて 均一ではありえない。しかしこのような油膜の状態に於て一固体 表面の影管を受けた脂肪酸分子のうちには上層をで方向性を示す あのがあり, 飽和脂肪酸柔の方向配列阅する㟶素数の境界は電 子週折㳻によつて $\mathrm{C}_{4} \sim \mathrm{C}_{6}$ とせられている2)。これらの脂肪酸洷 布膜上に銅ボールをのせる際，その接触部に於て油膜の上周にあ る分チは, ボール表面の影繁を受けて一部は反転して附着する分 子す生じてくるであろう。いま幾何学的平面間にある $\mathrm{C}_{6} \sim \mathrm{C}_{18}$ の 和脂肪酸油膜について考えてみよう。脂肪酸分子は表面力の影
響を受けて，両表面に極性基を面の方向に向けて配列し，その中 間にある分子㬝も整然たる配列を示しているものと思われるが， 多くの分子は相互に双極モーメントの面に垂直方向の成分は打ち 消しあい，一部の中閒賣にある分子㬝 (その分子周のうちで互に 打ち消しあ.5ものを生ずる場合もあ万う) によつて, 電気二重㬝 がつくられるすのと推察される。従つて $\mathrm{C}_{6} \sim \mathrm{C}_{18}$ の各脂肪酸の双 極モーメントは相等しいと考兄られるから，この二重層にもとづ く方向配列した脂肪酸油膜の示寸整流作用もほぼ相等しいと推察 される。凑際の鋼表面は微視的凹凸队策があり，油膜が著しく 荷重を受ける部分もあつて，幾何学的平面間に整然と配列してい ることは考兄られないから，統計的意味に於て油膜の非対称性に 由来することとなる。要するに本実験轺果から鋼二面閒にある飽 和脂肪酸采の配列に関する境界が， $\mathrm{C}_{6}$ にあることは明かである。 又油膜の示す整流作用を測定することによつて，同一系列に属す る油分子の方向配列の良否の程度を知りらることを示唆してい る。

次に摩擦の間題について考えてみよ5。Bowden 氏の動摩攃の 実験に於て飽和脂肪酸采の摩擦に関する臨界炭素数は $\mathrm{C}_{6}$ であり (第 2 区), 又著者等子静止摩擦俰数 (鋼-鋼) の測定に於て全く同

第 2 因

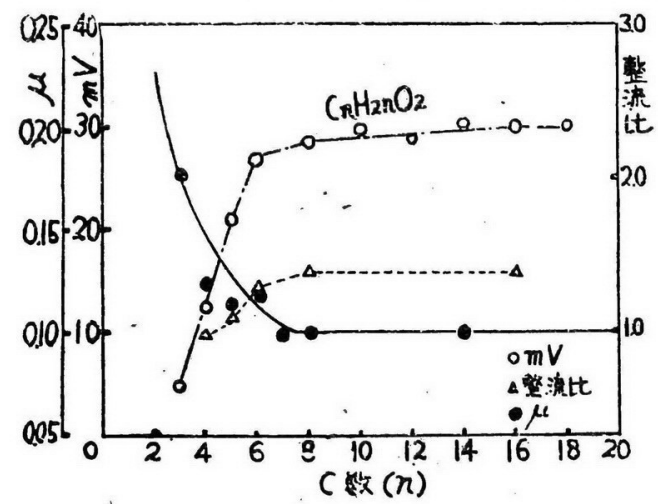

じ傾向にあることを認めている(後報)。すなわち $\mathrm{C}_{6}$ と $\mathrm{C}_{6}$ とは潤 滑性能に於て著しい相違を示し， $\mathrm{C}_{6}$ のカプロン酸になると stickslip の現象は全〈認められなくなる1)。第 2 図にみるように両者 の傾向は全く一致し，配列分子層が熱的及び機珹的挸乱)4)を伴わ ない条件に於ては，油分子の方向配列之境界摩摖との間には滵接 な関連性があるるのと考兄られる。な敃鋼二面閒にある油膜の配 列に関する結果と電子畐折法による結果が，脂肪族デェステルの 場合（続報）と異つて，一致したことは $\mathrm{C}_{5}$ と $\mathrm{C}_{6}$ とでは境界分 子層に於ける分子の挙動に著しい相違があるものと考えられ, こ れは同時に摩摖の場合の傾向を説明するるのでもある。

$$
\text { ま と め }
$$

鋼二面間に於ける飽和脂肪酸薄膜の示す整流作用に関する実験 を行い，同系列油分子の方向配列について検討した。

(1) $\mathrm{C}_{3} \sim \mathrm{C}_{18}$ の脂肪酸薄膜の示す整流作用は $\mathrm{C}_{3} \sim \mathrm{C}_{6}$ まで直 線的に増大し， $\mathrm{C}_{6}$ を境界として $\mathrm{C}_{8} \sim \mathrm{C}_{18}$ の間ほぼ一定值を示すに 至る。（2）従つて鋼二面間に於ける飽和脂肪酸の配列に関する 境界は $\mathrm{C}_{6}$ であることが推察せられ, 従来得られている電子䢙折 法の結果と一致し, 又動摩擦の臨界炭素数とも一致する。(3) $\mathrm{C}_{5}$ と $\mathrm{C}_{6}$ とは境界分子㬝に於ける挙動に著しい相違を示すことが考

4）曾田範宗, 宫川行雄, 理工研報告 2,49(1948). 
之られ，配列分子層の熱的及び機娥的嗳乱の伴わない条件に於て

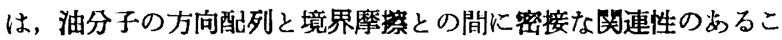

とが寨われる。

本研究は交部省科学研究費を仰いで行われたるのである。又

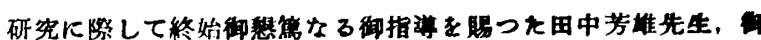

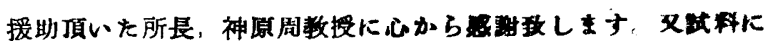

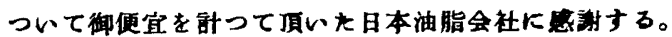

（酸水素油脂工業株式会社伙見工堨研究空）（昭和 26 年 11 月 16 日受理）

（150）オートクレーブ法による油脂加水分解に関する研究（第 8 報）

高圧オートクレーブによる油脂加水分解中間工業実殹

\section{米勢 千 鶴 男}

\section{緒管}

著者は水素加圧の下にステンレススチーえ製オートクレーブを 用い椰子油，バーム油，药麻子油及びその他の動植物油並びにそ れ等の硬化油等について無触媒による油脂加水分解に関する多数 の実験を試み，分解条件の選択によつて分解促進剂を添加しない 場合でる極く短時間に加水分解の進行することを確認し得た。次 で本報に於ては耐圧 $600 \mathrm{~kg} / \mathrm{cm}^{2}$, 容量 $15 l$ の 2 基の反会筒を主 体とするニッケルクロムスチール製中間工業実験装置を用いて， 中間然験を行つた結果について簡単に報告する。

\section{実 験 の 部}

（1）供㔀油の性狀 本実験には次の如き性状の硬化長須鯨油 を用いた。䠯化価 188.7, 酸洒 1.5，沃素価 (Wijs 泆) 35.4。

（2）実験裝晋及び方法 恝験装置は元来連続水素添加用とし て製作したもので、ニッケルクロムスチール製 (18-8) 耐圧 600 $\mathrm{kg} / \mathrm{cm}^{2}$, 容量 $15 l$ の 2 基の反応筒を主体とする装置であり, 油脂 加水分解用としては不備な点は多々あつたがこれを利用して中間 工業実験を試みた。以下実験装置の主要部について略述する。

（1）常圧分離器は鉄板製 $15 l$,（2）高圧分離器はマイルドスチ ール䡈常用压 $300 \mathrm{~kg} / \mathrm{cm}^{2}$, 容量 $15 l$, (3) 冷却器はステンレススチ ール製引技鋼管を用いスパイラルに巻き,鉄板製円筒内に装置す。 （4）反応筒はニッケルクロムスチール製 (18-8) にて容唔 $15 l$ 常 用圧 $300 \mathrm{~kg} / \mathrm{cm}^{2}$ (耐圧 $600 \mathrm{~kg} / \mathrm{cm}^{2}$ ), 耐熱温度 $450^{\circ} \mathrm{C}$, 加熱方 沠は電熱により完全に保温装置を施した。（5）蓄圧機廉除水器は マイルドスチール製常用圧 $300 \mathrm{~kg} / \mathrm{cm}^{2}$, 容量 $15 l$, (6) 予突器は ステンレススチール製で加熱は電熱による。(7) 循環ボンプ; 常 用压 $300 \mathrm{~kg} / \mathrm{cm}^{2}$, 能力 $100 \mathrm{l} / \mathrm{hr}$ ，（8）水素ガス任樎機は常用压 $300 \mathrm{~kg} / \mathrm{cm}^{2}$, 能力 $45 \mathrm{~m}^{3} / \mathrm{hr}$ 横型 3 段圧縮式（9）加熱用電熱は容 量 $10 \mathrm{~kW}$ の変圧器で調整する。

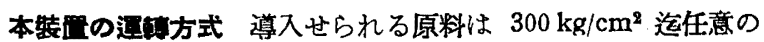
圧力で送入し得る圧送機により先ず予熱器に送入し加熱せられ， 他方水素ガスは $300 \mathrm{~kg} / \mathrm{cm}^{2}$ 迄任意の圧力に圧縮し得る水素ガス 压縮機によつて圧縮せられ, 䔞圧機兼除水器を経て水分を除去せ られた後，原料油と混合して予熱器に入り加䓡せられつつ反㳊筒 に入る。反応筒より流出する反応生成物及び過剩の水素は冷却器 を経て高圧分離器に入り，液状物とガス状物に分れ湤状物は低压

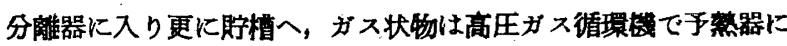
送り前記操作を反覆する。

実驗法 供試硬化長須鎬油 $5 \mathrm{~kg}$ に対し水 $6.5 \mathrm{~kg}$ (1:1.3) を添 加する。先ず反底筒を約 $240^{\circ} \mathrm{C}$ に加熱し同温度に於て水秉圧 85 $\mathrm{kg} / \mathrm{cm}^{2}$ をで充填し，次に原料油及び添加水を前記圧送清に上り仕 込む。原料仕込によつて一時下降した温度の上昇をまち $240^{\circ} \mathrm{C} に$ 達してよりの時間を分解所要時間とした。分解時中水素ガス循環 機によつて水素を循環し，摫汼の目的を以てガス排出バルブより 少量のガス排出を継䌇して行つた。央駼終了後温度の降下゙をま 排出バルブより水素を放出して，次に分解生成物を排出した。分 解生成物は水洗脱水後特数を湘定した。

\section{実験結果及び考窑}

.実験は次の条件下゙で実施した。（実臨日時昭和 23.8.15）

分解应件 分解温度 $240 \sim 250^{\circ} \mathrm{C}$, 実験圧 $56 \sim 85 \mathrm{~kg} / \mathrm{cm}^{2}$, 分解 時間 2 時間。买験終了後排出した分解生成物であるレリセリン甘 水は, 排出時の温度高きため乳白色に混淦し反沓内で简内完全な 乳化状態を証むることを得た。脂肪酸展よりその一部を探取して 試料とし，完全に水洗脱水後特数を測定した結果は次の如き性状 を示した。

\begin{tabular}{|c|c|c|c|c|}
\hline 実験番号 & 酸 価 & 分解率 (\%) & 捡化価 & 厂セチ几佂 \\
\hline 1 & 175.7 & 90.6 & 194.3 & 33.6 \\
\hline 2 & 181.0 & 92.8 & 195.0 & $\longrightarrow$ \\
\hline
\end{tabular}

次にグリセリン甘水 $1 \mathrm{~kg}$ (比重：1.020, $n_{1}^{20}: 1.3430$ )を採り

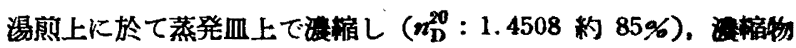
について日本薬局方規格によるアクロレイン検出试験を行つた結 果アクロレイン反底を怒めなかつた。

本实殹は水素ガス循謤機による水莱の循聚のみによつて队容物 の撜拌を行つたため，提拌は不充分であつたか㸮解時間 2 時間で 分解凉約 $90 \%$ 以上を示し，実験室に於ける小型オートクレーブ による実験結果にほぼ近い結果を得，一般工羊用オートクレーブ

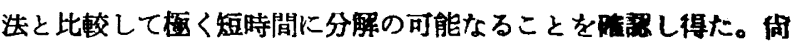
試料排出口不備のため分解過程中の試枓の採取は不能につき，分 解過程中の分解率及びア七チル価は湘定出来なかつた。

括

本報に於ては酎区 $600 \mathrm{~kg} / \mathrm{cm}^{2}$, 容量 $15 l$ の 2 基の反底籍を主 